\title{
INFLUENCE OF NON-STRUCTURAL COMPONENTS ON LATERAL STIFFNESS OF TALL BUILDINGS
}

\author{
R.K.L. Su ${ }^{a^{*}}$, A.M. Chandler ${ }^{a}$, M.N. Sheikh ${ }^{a}$ and N.T.K. Lam ${ }^{b}$ \\ ${ }^{a}$ Department of Civil Engineering, The University of Hong Kong, Pokfulam Road, Hong Kong \\ ${ }^{\mathrm{b}}$ Department of Civil and Environmental Engineering, The University of Melbourne, Parkville, Victoria 3052, \\ Australia \\ * Corresponding author. E-mail: klsu@hkucc.hku.hk $\quad$ Tel.: +852 $28592648 \quad$ Fax +852 25595337
}

\section{SUMMARY}

A building is a complex assemblage of both structural and non-structural components (NSC). Although many NSC, such as partition walls, external walls, parapet walls, stairwells, elevator shafts, and so forth, are connected directly to the structural system, their behaviour and stiffening effects under lateral loading have normally been ignored by design engineers, despite significant advances in computer technology and the availability of modern computational resources. The performance of structures can be greatly improved by the increase in strength arising from the NSC; on the contrary, this increase in strength also accompanies an increase in the initial stiffness of the structure, which may consequently attract additional seismically induced lateral inertia forces. This paper is concerned with the estimation of the lateral stiffness contributed by the NSC to the total stiffness of three common forms of tall building structures constructed in Hong Kong. Both dynamic tests and numerical modelling of the buildings have been carried out for this purpose. Natural period estimates from dynamic tests and from analyses using calibrated finite element models were found to be in remarkable agreement. Significant stiffness contributions from NSC to the total lateral stiffness of tall buildings have been observed in the study. The extent of the contributions depends on the structural form and the type of components. Other contributions to the additional stiffness have also been analysed for comparison in the study.

Key words: Non-structural components, lateral stiffness, tall building, bare-frame, full-frame, dynamic test.

Abbreviated Title: Non-structural components in tall buildings. 


\section{INTRODUCTION}

Despite significant advances in computer technology and the widespread availability of modern computational resources, it is common practice for design engineers to neglect non-structural components (NSC), such as partition walls, external walls, parapet walls, stairwells, elevator shafts, and so forth, in the mathematical modelling of a building for design purposes. The effect of a single NSC on the stiffness of a building may be negligible, but the cumulative effect of several components is expected to be significant. Full-scale ambient vibration measurement of tall buildings in Hong Kong shows that analytical models do not give frequencies that concur with test results (Su et al., 2003). This may be the direct consequence of improper modelling of some of the structural elements, as well as neglecting the contribution of NSC to the lateral stiffness.

There is no consensus amongst structural earthquake engineers regarding the influence of the NSC on the earthquake resistance and seismic safety of reinforced concrete buildings. The performance of the structure can be greatly improved by the increase in strength due to contributions from the NSC. On the contrary, this increase in strength would also accompany an increase in the initial lateral stiffness of the structure, which may consequently attract an increase in the seismically induced inertia forces. The resulting influences on the seismic performance of the building are difficult to generalise as they depend a great deal on detailing and load transmission paths within the building. The displacement demand on the building would normally be decreased, when displacement controlled actions (eg. storey drifts) are mitigated accordingly. However, force controlled actions (eg. column shear and joint shear) could be accentuated by the decrease in the natural period, and hence increase in the base shear, of the building.

Conventional construction practice in Hong Kong employs concrete block masonry walls, lightweight concrete walls and dry walls placed in the frames and structural walls without any separation. Such walls have normally been considered as NSC, and their presence has been ignored by engineers. Even in some recent editions of major seismic codes (such as IBC-2000), the influence of NSC walls has been neglected. Although they are considered as NSC, they undergo interaction with the structure when it is subjected to lateral loads. 
A literature survey indicates that only a few studies have quantified the contribution to lateral stiffness of the NSC. Some researchers have studied the effect of masonry infill panels on the stiffness and strength of frames/buildings [refer Table 1]. Significant effect of masonry infill panels has been observed, although the variation in stiffness ratio between the bare-frame and the infilled-frame is large. Shing et al. (1994) and Mehrabi et al. (1996) found that the stiffness of a weak frame-strong panel model could be as high as 50 times that of a bare-frame model. For a 6-storey three bay frame structure, Yong Lu (2002) found that the stiffness ratio of the infilled-frame and the bare-frame was in the order of 1.2, which was much lower than findings from other studies. However, the building subject to the study was only partially infilled and measurements were taken only from the second storey of the building. Consequently, the actual global stiffness of the infilled-frame could be even higher than the reported value. Negro and Verzeletti (1996) conducted pseudo dynamic tests on a 4-storey partially infilled RC building and reported the stiffness ratio between the bare-frame and the full-frame model of the building as 2.6 (in terms of stiffnesses) and 1.6 (in terms of strength). Both ratios were significantly lower than those reported in other studies. It should be noted that, for the building studied, infill walls were employed only for the two external frames.

Most of the studies considered in the above literature survey [refer Table 1] and also from other studies on infilled RC frames/structures (Mehrabi et al., 1996) have been conducted on small-scale RC buildings/frames or frame designs that might not truly reflect existing building structures. Masonry infill walls, being traditionally non-engineered, have as-built properties which at the design stage are almost impossible to estimate reliably and/or to specify, and at the construction stage are hard to control (Fardis et al., 1999). Moreover, the geometry of masonry infill walls may be subject to alteration during the service life of the structure.

In obtaining accurate estimates of the stiffness contributions from NSC in existing buildings, these issues must be considered in both analytical and experimental modelling. None of the above studies have been conducted on a high-rise building, which is the focus of the present study. The scope of this paper is limited to the influence of the NSC (partition walls, external walls, parapet walls, and precast-façade walls) on the initial in-plane building stiffness at small strains. Effects of NSC on the lateral strength or on the stiffness and strength eccentricity of the structure are beyond the scope of the paper. Furthermore, 
linear elastic behaviour of the building based on the properties of uncracked concrete has been assumed. Thus, the deterioration in the structural strength and/or stiffness of the building with increasing strain under cyclic conditions has been neglected. Ambient vibration measurements were conducted on three high-rise buildings $(14,15$ and 41 storey) to determine their natural frequencies in the longitudinal, transverse and torsional directions for the calibration of finite element (FE) models. The lateral load resistance of the three buildings considered here comprise a moment-resisting frame structure, a framewall structure and a shear wall structure. These three types of structural systems represent most tall buildings existing in Hong Kong and elsewhere. The period estimation of FE model calibration for the full frame building and the ambient vibration tests are found to be in remarkable agreement. Lateral stiffness of the building has been calculated from the effective mass and the frequency of the building. A significant contribution of NSC to the total lateral stiffness of the buildings has been observed, but the magnitude of the contribution depends significantly on the structural form and the type of NSC.

\section{DESCRIPTION OF THE TESTED BUILDINGS}

a) Swire building (SB)

$\mathrm{SB}$ is a 15 -storey RC building located in the main campus of the University of Hong Kong (HKU) and completed in 1980. It mainly serves as a student hall. The building is irregular in shape and consists of two parts. The lower part of the building, from lower ground floor to ground floor, is rectangular in shape. The upper part, from upper ground floor to penthouse floor, is H-shaped. The typical height of lower part floors is $3.6 \mathrm{~m}$, whereas for the upper part floors it is $2.9 \mathrm{~m}$. The plan dimensions of the building are $47.5 \mathrm{~m} \times 32.6 \mathrm{~m}$ with a total height of $51.3 \mathrm{~m}$ from the base. The lateral force resisting structural system consists of RC moment resisting frames attached to the concrete core walls at the centre and four shear walls at the edges [refer Figure 1a]. Typical depth of the beams is $700 \mathrm{~mm}$, and the thickness of shear walls is $300 \mathrm{~mm}$. Internal and external non-structural walls are built of concrete bricks. Steel H-pile and pile caps form the foundation of this structure. As the building is located on sloping ground, part of the basement is bounded by $230 \mathrm{~mm}$ thick RC screen walls to resist the soil pressure. The specific grade strength of concrete $\mathrm{f}_{\mathrm{cu}}$ for all the structural members is $30 \mathrm{MPa}$. 
b) TT Tsui Building (TTT)

TTT is a 14-storey RC building located in the main campus of HKU, and was completed in 1996. It serves as an academic building, as well as housing the university art and museum gallery. The plan dimensions are $28.4 \mathrm{~m} \times 23.3 \mathrm{~m}$ with a height of $52.8 \mathrm{~m}$ from the base. The lateral force resisting structural system consists of RC moment resisting frames attached to the concrete core walls located at one side of the building that support the lift lobby and staircases [refer Figure 1b]. Typical depth of the beams is $650 \mathrm{~mm}$, and the thickness of shear walls is $350 \mathrm{~mm}$. As the structure is founded on a slope, the thickness of some of the walls in the lower storeys ranges between 500 and $550 \mathrm{~mm}$. The interior and exterior walls consist of infill concrete walls of $125 \mathrm{~mm}$ thickness. Bored piles and pile caps form the foundation of this structure. The specific grade strength of concrete $f_{\text {cu }}$ for all the structural members is $30 \mathrm{MPa}$.

\section{c) Typical Harmony Blocks (THB)}

Harmony blocks are standard housing towers that were designed to be constructed on a repetitive basis at various sites throughout the territory of Hong Kong. The first Harmony Block building contract commenced in late 1989 and was completed in late 1992 (Hong Kong Housing Authority, 1993). According to statistics obtained from the Housing Authority (Hong Kong Housing Authority and Housing Department), there are at present 67 public rental estates having one or more harmony blocks.

The harmony block building selected for this study is located in the New Territories (in Hong Kong) and its construction was completed in 1996. It is a 41-storey RC shear wall building having plan dimensions of $53 \mathrm{~m} \times 48 \mathrm{~m}$ and a height of $112.7 \mathrm{~m}$ from the base. The structure has four similar wings which are symmetrically arranged in the longitudinal and lateral directions with a cruciform configuration and are attached to the central core of the building where services, lifts and staircases are located. The building core accommodates 6 lift shafts and 2 staircases. Coupled shear walls together with the core walls provide the overall lateral stiffness of the building [refer Fig 1c]. The wall thickness varies from $200 \mathrm{~mm}$ at the higher zone to $300 \mathrm{~mm}$ at the lower zone of the building. Some of the internal shear walls are changed to columns at the ground floor non-domestic storey to accommodate ancillary facilities. The floor slabs are designed as one-way or two-way spanning plates supported by shear walls, and the typical thickness of the floor slabs is $170 \mathrm{~mm}$ in living rooms and $300 \mathrm{~mm}$ in corridors. The internal walls forming the 
kitchens and bathroom areas, along with the external facades, are NSC. The internal non-structural walls are constructed of full height pre-cast partition panels of $150 \mathrm{~mm}$ thickness. The building is supported on piled foundations. The specific grade strength of concrete $\mathrm{f}_{\mathrm{cu}}$ of all the structural members is $30 \mathrm{MPa}$.

\section{DYNAMIC TESTING OF BUILDINGS}

Dynamic testing has involved components or scale models of the whole structure to correlate systematically with FE analysis, in order to improve or update the analytical models from which structural parameters can be identified (Memari et al., 1999 and Brownjohn \& Xia, 2000). As scale models cannot accurately account for the three dimensional interaction of structural and NSC or the quality of construction among other parameters, full-scale dynamic testing of existing structures is most appropriate in light of new demands for seismic evaluation of existing structures (Memari et al., 1999). One of the basic objectives is to obtain dynamic structural properties such as frequencies, mode shapes, and damping ratios in order to compare with the results from analytical FE modelling and hence to verify or correct the parameters such as mass distribution, stiffness and damping (Foutch, 1977 and Aktan \& Ho, 1990). Another important application of dynamic testing of civil infrastructure is to check for continuing structural integrity, as buildings and bridges age and are subject to ever increasing loads, or after some specific damaging event such as an earthquake (Brownjohn, 2003).

The most widely used methods of full-scale dynamic testing include forced vibration tests (FVT) and ambient vibration tests (AVT). In some cases, it may be possible to excite the building artificially while at the same time measuring the applied load due to an electro-dynamic, hydraulic and machine shakers. For buildings, traditionally, rotating eccentric mass (REM) shakers are used for stepped sine-testing (Littler, 1988), and in rare cases shakers driven by hydraulic or electro-dynamic actuators are used to excite a building with a broad band signal (Williams \& Tsang, 1988). The motivation for FVT is that traditional modal analysis procedures such as circle fit could be used, often with higher accuracy in identifying some of the parameters, particularly the damping ratios (Brownjohn, 2003).

Unlike FVT, which requires sophisticated and expensive equipment, ambient vibration tests (AVT) can be performed with relative ease and affordable equipment. As the AVT test does not require the facility to 
be shut down, normal everyday operation can continue while testing is being carried out. Experimental investigations have shown close agreement in the mode shapes and frequencies from both FVT and AVT (Sparks et al., 1980; Foutch et al., 1974; Mendoza \& Reyes, 1991). The response of a structure to ambient excitation (wind, traffic or people) is such that it tends to vibrate primarily in its natural modes, and hence with spectral analysis its dominant frequencies can be determined. As the purpose of dynamic testing for this study is to determine the fundamental frequency of the buildings, only AVT has been carried out.

The ambient responses of the selected buildings were measured with an 8-channel data acquisition system using IMV corporation VP-5122 model uni-axial servo type accelerometers, connected by shielded cables to a signal conditioner and $12 \mathrm{bit} \mathrm{A} / \mathrm{D}$ converter. Its range of operation varies from 0.001-1.0g and the rated output is 5 volts. The accelerometers convert the kinetic energy of movements of the building into usable electric output. This electrical signal is then passed though a signal conditioner. The signal conditioner scales the electric signal according to the individual characteristics of each accelerometer, and adjusts the analogue output accordingly. This analogue signal is converted to a series of discrete outputs by the $\mathrm{A} / \mathrm{D}$ converter. A notebook computer was used for acquisition and storage of these outputs. For each set up, the data was recorded for duration of 15 minutes at a rate of 256 samples per second. Highspeed data acquisition software GLOBAL LAB was used to analyse the acquired data. It can simultaneously scan the accelerograms and display the readings automatically. A schematic diagram of the data acquisition system has been shown in Figure 2.

The characteristic frequencies in each vibrational direction were determined from the peak amplitudes of the power spectra that were determined from spectral analysis of the recorded time histories by applying the Fast Hartley transform (FHT) technique. Cross-spectral analysis has been performed in order to identify the transverse, longitudinal and torsional modes of the buildings. In cross spectrum analysis, spectral density is estimated by summing up the product of FHT of the two parallel signals. Frequencies at which the amplitudes are positive and negative indicate the lateral modes and torsional modes, respectively. Detailed discussion on AVT in identifying the frequency characteristic together with the mode shapes and damping of buildings can be found in Ivanovic et al. (2000). 
Dynamic analysis of the buildings has been carried out using the methodology described above. The arrangements of accelerometers in the buildings have been shown in Figure 3. A typical time history record (of 4 minutes duration) of the Swire Building (SB) and the corresponding power spectrum have been shown in Figure 4(a-c). The fundamental assumption of AVT is that the inputs causing motion have white noise characteristics in the frequency range of interest. This assumption implies that the input loads are not driving the system at any particular frequency and therefore any identified frequency associated with signal strong response reflects structural modal response. In reality, however, some of the ambient disturbances may drive the structure at that frequency. In this case it appears that the disturbance is dominant in the frequency range $70-100 \mathrm{~Hz}$ (refer Figure 4b), as the expected frequency of the building is around $1.0 \mathrm{~Hz}$. The typical power spectrum after applying a low-pass filter has been shown in Figure 4c.

The measured periods from the ambient vibration tests have been summarized in Table 2 for the first three dynamic modes. It has been observed that the fundamental periods of the buildings are considerably smaller than the estimations employing the empirical formulae of the IBC and Australian standards [refer Table 3]. It is further noted that buildings in Hong Kong have not been engineered to resist major or even moderate earthquakes, although the region has been considered to be a moderate seismicity region [Chandler \& Lam, 2002; Lam et al., 2002; Chandler et al., 2002]. Traditionally, buildings and structures are required to be designed for typhoon wind load ignoring the effect of earthquake. For this reason, buildings in Hong Kong are usually considered to be stiff when compared with similar structures from the United States, Australia or Europe. This may be due to the fact that tall buildings in Hong Kong are normally constructed of stiff structural forms rather than flexible moment resisting frames. Considering the average density of the building, Su et al. (2003) remarked that Hong Kong buildings are not only stiffer but also more massive than overseas counterparts. As the proportion of added stiffness, due to larger member sizes, is usually greater than the added mass, hence the fundamental period is lower for Hong Kong buildings. 


\section{FINITE ELEMENT MODEL CALIBRATION}

The computer program ETABS Non-linear 7.22 (Computers and Structures Inc., 1999) was used to develop finite element (FE) models for the buildings. The program can perform linear and non-linear, static and dynamic analyses. In ETABS, buildings are idealized as an assemblage of area, line, and point objects. These objects are used to represent different elements such as columns, beams, walls and slabs. Three dimensional mode shapes and frequencies, modal participation factors, directional factors, and modal effective mass factors can be evaluated by either eigenvector or Ritz-vector analysis. In this study the frequencies and modal effective mass factors were evaluated using eigenvector analysis.

A number of assumptions were made in order to build the analytical FE model of the buildings: (i) Linear elastic material properties were used for 3-D modal analyses; (ii) the building masses were lumped at the floor levels; (iii) self weight of the elements was calculated independently from the program [refer below]; (iv) the base was assumed to be fixed and soil-structure interaction was neglected; (v) beam-tocolumn connections were fixed (moment resisting frame assumption); (vi) shear walls and floor slabs were used as plate bending elements; and (vii) no rigid-offsets were used to model beam-to-beam or beam-to-column connections.

Initially, bare frame models were developed; only the major structural elements such as primary beams, columns, and walls were modelled. The floor diaphragms were considered rigid in plane and flexible normal to the plane. Dead load and live load of each floor were calculated and lumped at the centre of mass of the floors. The calculated loadings were obtained from the product of member size specified in the drawings and their corresponding densities. As the arrangement of NSC is different in each floor, the mass of each floors was calculated separately. The specific grade strength of concrete $f_{\text {cu }}$ for all the structural members was assumed as $30 \mathrm{MPa}$, as mentioned above.

Several modifications have been made to the bare frame model for calibration with the full frame models [refer Figure 5] and for comparisons with results obtained from dynamic analysis for the numerical 
modelling of bare-frame and full-frame models. These modifications have been described in the following under separate sub-headings:

\section{a) Modification for elastic modulus of concrete:}

Recently Kwan et al. (2001) carried out a series of tests on the elastic modulus of normal- and highstrength concrete and proposed the following correlation equation, which is valid for concrete strengths ranging from 5 to $140 \mathrm{MPa}$.

$\mathrm{E}_{\mathrm{c}}=3.46\left(\mathrm{f}_{\mathrm{cu}}\right)^{1 / 2}+3.21$

where $E_{c}$ is the elastic modulus of concrete (in $\mathrm{GPa}$ ) and $\mathrm{f}_{\mathrm{cu}}$ is the compressive strength of concrete (in $\mathrm{MPa}$ ). This equation has a correlation coefficient of 0.967 and a standard error of estimate of 2.56.

According to Hong Kong construction regulations [Building (Construction) Regulations, 1996], the specific concrete strength has to be $5 \mathrm{MPa}$ higher than the design concrete strength (for concrete grade of 20 or above). Hence the elastic modulus of concrete needs to be increased by considering the increased grade strength.

Structural concrete is usually strengthened by the presence of reinforcement that will affect the elastic modulus (E) of concrete assumed in dynamic modelling. The E value of reinforced concrete (RC) may be estimated by

$\mathrm{E}_{\mathrm{rc}}=\mathrm{E}_{\mathrm{c}}(1-\rho)+\mathrm{E}_{\mathrm{s}} \rho$

where $\mathrm{E}_{\mathrm{rc}}$ is the static modulus of RC (in GPa), $\mathrm{E}_{\mathrm{s}}(=200 \mathrm{GPa})$ is the elastic modulus of RC, and $\rho$ is the steel ratio.

The above considerations in the prediction of the $\mathrm{E}$ values in $\mathrm{RC}$ have been incorporated into the modelling for the bare-frame of the building.

\section{b) Modification for NSC:}

Internal and external non-structural walls are made of concrete bricks or concrete blocks in the SB case study; concrete infills are of grade 20 concrete in the TTT case study; and dry walls made of autoclave aerated concrete (AAC) in the THB case study. Properties of concrete bricks and blocks may vary 
depending on the manufacturer. Lau (2003) conducted an experimental study for the mechanical properties of common types of concrete bricks and blocks and concluded that their average density was $2000 \mathrm{~kg} / \mathrm{m}^{3}$, compressive strength $11.5 \mathrm{MPa}$, modulus of elasticity $8 \mathrm{GPa}$ and Poisson's ratio 0.15 . AAC, commonly known as drywall, is manufactured from sand, lime, PFA, cement, water and aluminum powder. Composed of calcium silicate hydrates, AAC is very porous and has average density in the order of $550 \mathrm{~kg} / \mathrm{m}^{3}$, compressive strength $5.0 \mathrm{MPa}$, and modulus of elasticity $2.0 \mathrm{GPa}$.

All the external and internal non-structural walls, parapet walls, and precast-façade walls have been added to the bare frame models.

\section{c) Modification for secondary beams}

Usually in bare-frame models, secondary beams are ignored and hence the contributions of such beams to the total building lateral stiffness have been neglected. Although the contributions to stiffness from such beams may be small, ignoring such contributions may lead to some underestimation of the building stiffness. Secondary beams have been identified from working drawings and incorporated into the analytical model of the building.

\section{d) Modification for flexible floor diaphragms}

Building models of high-rise buildings often adopt the rigid-floor diaphragm assumption for the entire floor slab. When such an assumption is made, the flexural stiffness of the floor slabs is usually ignored in the analysis. This assumption may be reasonable for framed structures consisting of beams and columns, but not for shear-wall structures in which the structural walls have a lateral stiffness comparable to that of the floor diaphragm (Boppana \& Naeim, 1985). Increasing the flexural stiffness of the floor slabs would increase the degree of coupling with the shear wall panels, and hence the overall lateral stiffness of the structure. This influence from the wall-slab coupling increases with the number of storeys in the building (Lee \& Kim, 2000; Lee et al., 2002). Ignoring contributions from the floor slabs in flexure could result in the lateral stiffness of the building being significantly underestimated. The underestimation in the building stiffness could result in the natural period of the building being overstated significantly. To 
account for the stiffness contributions from the floor slabs in flexure, flexible slab elements have been incorporated into the analytical model of the building.

To quantify the effects of the above modifications, six analytical models have been developed for each of the case study buildings. These analytical models are:

(a) initial bare frame model;

(b) bare frame model which accounts for modifications to the $\mathrm{E}$ value;

(c) bare-frame model as for (b) but with contributions from the NSC incorporated ;

(d) bare-frame model as for (b) but with contributions from the secondary beams incorporated ;

(e) bare-frame model as for (b) but with contributions from the floor slabs incorporated ;

(f) full-frame model which has accounted for all the modifications.

The resulting periods for the first three modes obtained from eigenvalue analysis have been listed in Table 4. The distinction between modes was based on the modal direction factors (Computers and Structures Inc., 1999). It can be observed that, from Column 7 and Column 8 of Table 4, analytical results for lateral periods differ from the experimental investigation results by only 2 to $4 \%$. Hence the numerical modelling can be considered as an accurate representation of the actual building.

An important observation from the results of numerical modelling is that the natural periods of the bare frame model, for the three tall buildings considered here, are much higher than the full frame model. In all cases, except the torsional mode in the THB building, the differences are more than $100 \%$, and for the torsional mode in TTT building the difference reaches $342 \%$. Hence it can be concluded that the natural period of the building could be grossly over-estimated by analyses using the "initial bare-frame" model described above. The over-estimating of the natural period of the building would accordingly result in the under-estimation of the design seismically induced inertia forces and base shear. 


\section{DETERMINATION OF EFFECTIVE LATERAL STIFFNESS}

The effective lateral stiffness of the building can be determined in accordance with the calculated effective mass and the fundamental natural frequency (or natural period) of the building, based on the idealisation of a lightly damped single degree of freedom system using Eq.3:

$K=\mathrm{M}_{\mathrm{e}}(2 \pi \mathrm{f})^{2}$

where $M_{e}$ is the effective mass (which can be calculated from modal participation mass factor) and $f$ is the fundamental natural frequency of the building. Values of the stiffness have been calculated for each modification. By comparing the modifications, the contributions from each component has been calculated and expressed as the proportion of the total stiffness of the building [refer Table 5].

It can be observed from Figure 6 that the bare frame model for the Swire building (SB) accounts for only $22 \%$ of the total lateral stiffness of the building in the X-direction, and only $11 \%$ in the Y-direction. The highest contributions to stiffness are from the NSC, which are built of concrete bricks for this building. The contributions from the NSC amount to $61 \%$ in the lateral X-direction and $82 \%$ in the Y-direction. The reason for this directional difference is due to the fact that larger numbers of NSC are contained in the direction parallel to the Y-axis. Bertero and Brokken (1983) reported that infill walls made of hollow concrete bricks and concrete blocks increase the stiffness of bare frame models between $366 \%$ and $994 \%$. In the light of these findings, the stiffness contributions by NSC in the SB case study seem plausible.

The bare frame model in the T. T. Tsui (TTT) building case study accounts for only $9 \%$ of the total lateral stiffness of the building in the X-direction, and $11 \%$ in the Y-direction. As this building is mainly a framed structure with a core-wall located on one side of the building, the stiffness of the bare frame, which is mainly a beam-column frame, is rather low compared with the other two buildings studied. A significant increase in stiffness arising from the NSC has been observed, $87 \%$ in the lateral X-direction and $83 \%$ in the lateral Y-direction. The NSC comprises mainly concrete walls of grade 20 located at the periphery of the building frame. These non-structural walls basically formed a tubular structure within the TTT building and hence resulted in a significant increase in both the lateral and torsional stiffnesses. 
Chaker \& Cherifati (1999) also reported similar contributions from non-structural walls to the framed structure, and pointed out the fallacy of treating these infill panels as "non-structural' components.

The bare frame model in the THB case study accounts for approximately $25 \%$ of the total lateral stiffness of the building in the two orthogonal directions. Since the lateral stiffness of the THB bare frame model was derived mainly from shear walls, stiffness contributions from the bare frame model is the highest of all three buildings considered. Contributions from the NSC account for approximately $22 \%$ of the total lateral stiffness of the building, which is the least amongst all three buildings. In the THB building, the NSC mainly comprise dry walls that have been used as partition walls in the kitchen, wash rooms and walls at the corridor near the lift lobby. The modulus of elasticity of these dry walls is only 2 GPa. Memari et al. (1999) also found that the increase in building stiffness due to dry walls (ACC block walls) is substantially smaller than would be for the case of clay brick walls or concrete block walls. Another interesting observation is that stiffness contributions from flexible floor slabs account for $40 \%$ of the total lateral stiffness of the building (which is much higher than the other two case study buildings). The thickness of the floor slabs in the THB building is around $170 \mathrm{~mm}$ in living areas and $300 \mathrm{~mm}$ in corridors, which is again much higher than the other case study buildings. Lee et al. (2002) discussed the stiffness of floor slabs of the box-system structure composed of only RC walls and slabs and compared it with the frame structure. They concluded that the effect of the flexural stiffness of slabs on the lateral response of the shear wall structure is relatively significant, especially in taller buildings and in buildings with irregular arrangement of shear walls. Ignoring the effect of flexural stiffness of the slabs for this type of structure implies that the lateral displacement may be overestimated and the seismic loads given by the building code base shear may be significantly underestimated.

\section{DISCUSSION AND CONCLUDING REMARKS}

The results of ambient vibration tests and FE computer analysis provide a basis for a better understanding of the dynamic characteristics of buildings. The lateral load resistance of the three tall buildings considered herein comprise a frame structure, a frame-wall structure and a shear wall structure. These three types of structural systems represent most of tall buildings existing in Hong Kong and elsewhere. 
The principal objective of the work presented in this paper is to evaluate the stiffness contributions from NSC to the total stiffness of the building. Ambient vibration tests have been carried out to estimate the fundamental mode of vibration. Although several modes of vibration have been identified, only the first three modes have been presented here, as it has been considered sufficient for the purpose of the study. As the ambient vibration tests have been conducted only for the fundamental natural periods, and not for the mode shapes, details of the stiffness properties of the building, cannot be inferred from this experimental study.

The natural periods estimated by the calibrated FE models of the full frame building and those measured from the ambient vibration tests were in remarkable agreement (with discrepancies of only $2-4 \%$ ). Hence, the full frame model can be considered as representative of the true behaviour of the building [refer Table 4]. Several modifications have been made to the initial bare frame model in developing the respective full frame model for each case study building. Computer modelling of the NSC (partition walls, external walls, parapet walls, and pre-cast façade walls) have been conducted to estimate the effect of these components on the total lateral stiffness of the buildings.

As shown in Table 6, the bare frame model has been found to contribute as little as $9 \%$ to the total lateral stiffness of a tall building. The highest stiffness contributions from the bare frame has been found in the case study of the shear wall structure. Even then, this contribution accounts for only $25 \%$ of the total lateral stiffness of the building. In addition, other sources of stiffness, such as contributions from the modified E-value of the RC, secondary beams and floor slabs, have been considered in the comparative study.

The stiffness of full-frame models has been found to be 4-11 times that of bare-frame models [refer Table-6], which is consistent with the results shown in Table 1. The directional difference of stiffness ratio between bare-frame and full-frame models for SB is due to the fact that NSC are more numerous in the direction parallel to the Y-axis. The stiffness ratio has been observed to be the highest for TTT. The NSC in this building are mainly concrete walls of grade 20 located at the periphery of the building frame, 
forming a tubular structure which has lateral and torsional stiffnesses much higher than the initial bare frame of the building.

The extent of stiffness contributions from the NSC to the total lateral stiffness of the buildings has been found to depend on the structural form and the type of NSC (material type). NSC have been found to contribute as much as $87 \%$ to the total lateral stiffness of the building. Stiffness contributions from NSC have been found to be larger in framed structures than in shear wall structures. Drywalls have been found to contribute less to lateral stiffnesses than infilled concrete walls or concrete block/brick walls.

Commercial software, such as ETABS (Computers and Structures Inc., 1999), commonly used for FE analysis of high-rise buildings, assumes a rigid diaphragm for floor slab implying that their flexural stiffness has been ignored. This could lead to a gross underestimation of the total lateral stiffness of the building, especially for shear wall structures with thick floor slabs. For the THB building the contribution of the flexible floor slabs has been found to be around $40 \%$.

The overall influence of NSC components on the potential seismic performance of a building is difficult to generalise as the influence would depend a great deal on detailing and load transmission paths within the building. The displacement demand on the building would normally be decreased, and displacement controlled actions (eg. storey drifts) mitigated accordingly. However, force controlled actions (eg. column shear and joint shear) could be accentuated by the decrease in the natural period, and hence increase in base shear, of the building. This study enlightens our appreciation on how poorly the true dynamic behaviour of a building could be represented by contemporary analytical modelling. The modelling difficulties demonstrated in this paper have not even included the effects of stiffness and strength deterioration, which are equally as complex and difficult to predict.

Significantly, seismic hazard is currently expressed in terms of the elastic response spectrum, which is under-pinned by the notion that the natural period of a building is well defined and can be determined $a$ priori with good accuracy. Thus, this study not only highlights shortcomings in the current methods of 
modelling a building, but also prompts a critical review of the current seismic design and risk evaluation methodology as a whole.

\section{ACKNOWLEDGEMENTS}

The work described in this paper was substantially supported by a grant from the Research Grants Council of the Hong Kong Special Administrative Region, China (Project No. HKU 7103/03E) and the Committee on Research and Conference Grants of the University of Hong Kong (small project funding programme 2003-04), whose supports are gratefully acknowledged. Invaluable contributions by final year project students Mr. Dennis Lee TK, Mr. Partick Lee CH, Mr. Goei YH, Miss Victoria Cheung WK and Miss April Lau CW in carrying out the dynamic tests and assessing the data are also acknowledged.

\section{REFERENCES}

Aktan AE, Ho I-K. 1990. Seismic vulnerability evaluation of existing buildings. Earthquake Spectra. 6 (3): 439-72.

AS1170.4: Standard Association of Australia. 1993. Minimum Design Loads on Structures, Part 4: Earthquake Loads, AS1170.4.

Bertero VV., Brokken S. 1983. Infills in seismic resistant building. Journal of Structural Engineering, ASCE. 109: 1337-61.

Boppana RR, Naeim F. 1985. Modelling of floor diaphragms in concrete shear wall buildings. Concrete International: Design and Construction. 7(7): 44-46.

Brownjohn JMW. 2003. Ambient vibration studies for system identification of tall buildings. Earthquake Engineering and Structural Dynamics. 32(1): 71-95

Brownjohn JMW, Xia PQ. 2000. Dynamic assessment of curved cable-stayed bridge by model updating. Journal of Structural Engineering, ASCE. 126(2): 252-260.

Building (Construction) Regulations. 1996. Chapter 123 Subsidiary legislation, Hong Kong Government Special Administrative Region. B(C)R. Hong Kong 
Chaker AA, Cherifati A. 1999. Influence of masonry infill panels on the vibration and stiffness characteristics of R/C frame buildings. Earthquake Engineering and Structural

Dynamics. 28(9): 1061-1065.

Chandler AM, Lam NTK \& Sheikh, MN. 2002. Response spectrum predictions for potential near-field and far-field earthquakes affecting Hong Kong: soil sites. Journal of Soil Dynamics \& Earthquake Engineering ; 22(6): 419-440

Chandler AM, Lam NTK. 2002.Scenario predictions for potential near-field and far-field earthquakes affecting Hong Kong. Journal of Soil Dynamics \& Earthquake Engineering. 22(1): 29-46.

Computers and Structures Inc. (CSI). ETABS User's manual. Berkeley, California, USA; December 1999; www.csiberkeley.com (last visited in November 2003)

Fardis MN, Bousias SN, Franchioni G, Panagiotakos TB. 1999. Seismic response and design of RC structures with plan-eccentric masonry infills. Earthquake Engineering and Structural Dynamics. 28(2): 173-191

Foutch DA, Housner GW, Jennings PC. 1974. Dynamic responses of six multistory buildings during the San Fernando earthquake. Report No. EERL 75-02, California Institute of Technology, Pasadena, CA.

Hong Kong Housing Authority and Housing Department. Public rental Housing. harmony blocks http://www.housingauthority.gov.hk/en/residential/prh/ (Last visited in November 2003)

Hong Kong Housing Authority. 1993. An Illustrated Summary Of 40 Years Of Public Housing Development In Hong Kong: 1953 to 1993 A Story Worth Telling. Hong Kong: Government Printer.

IBC-2000. International Code Council (ICC). International Building Code, U.S.A., 2000

Ivanovic SS, Trifunac MD, Novikova EI, Gladkov AA, Todorovska MI. 2000. Ambient vibration tests of a seven storey reinforced concrete building in Van Nuys, California, damaged by the 1994 Northridge earthquake. Journal of Soil Dynamics and Earthquake Engineering. 19(6): 391-411.

Kwan AKH, Lee PKK and Zheng W. 2001. Elastic modulus of normal- and high-strength concrete in Hong Kong. Transaction of the Hong Kong Institution of Engineers. 8(2): 10-15. 
Lam, NTK, Chandler AM, Wilson JL, Hutchinson GL. 2002. Response spectrum predictions for potential near-field and far-field earthquakes affecting Hong Kong: rock sites. Journal of Soil Dynamics and Earthquake Engineering. 22(1): 47-72.

Lee DG, Kim HS, Chun MH. 2002. Efficient seismic analysis of high-rise building structures with the effect of floor slabs. Engineering Structures. 24(2): 613-623.

Lee DG, Kim HS. 2000. The effect of the floor slabs on the seismic response of multi-story building structures. Proceedings of APSEC 2000, September 2000, Malaysia.

Lee HS, Woo SW. 2002. Effect of masonry infills on seismic performance of a 3-storey R/C frame with non-seismic detailing. Earthquake Engineering and Structural Dynamics. 31(2): 353-378.

Littler JD. 1988. Forced vibration tests on Sheffield University Arts Tower. In Proceedings of Conference on Civil Engineering Dynamics, Society for Earthquake and Civil Engineering Dynamics, Bristol, UK, March 1988; 61-80.

Lu Y. 2002. Comparative study of seismic behavior of multistory reinforced concrete framed structures. Journal of Structural Engineering, ASCE 128(2): 169-178.

Mehrabi AB, Shing PB, Shuller MP, Noland JL. 1996. Experimental evulation of masonry-infilled RC frames. Journal of Structural Engineering, ASCE 122(3): 228-237.

Memari AM, Aghakouchak AA, Ashtiany MG, Tiv M. 1999. Full-scale dynamic testing of a steel frame building during construction. Engineering Structures 21(12): 1115-1127.

Mendoza L, Reyes A, Luco JE. 1991 Ambient vibration tests of the Mexicali General Hospital. Earthquake Spectra. 7(2): 281-300.

Negro P, Verzeletti G. 1996. Effect of infills on the global behaviour of R/C frames: Energy considerations from pseudodynamic tests. Earthquake Engineering and Structural Dynamics. 25(8): 753 773.

Shing PB, Mehrabi AB, Schuller M, Noland JL. 1994. Experimental evaluation and finite element analysis of masonry-infilled R/C frames. In Proceedings of Conference on Analysis and computation, ASCE, New York, 84-93. 
Sparks PR, Jeary AP, de Souza VCM. 1980. A study of the use of ambient vibration measurements to detect changes in the structural characteristics of a building. In: Hart G, editor. Dynamic response of structures: experimentation, observation, prediction and control. ASCE, 1980:189-200.

Su RKL, Chandler AM, Lee PKK, To AP and Li JH. 2003. Dynamic Testing and Modelling of Existing Buildings in Hong Kong. Transactions of Hong Kong Institution of Engineers, 10(2): 17-25.

Lau CW. 2003. Structural assessment of buildings in Hong Kong under earthquake load. Final Year Project Report, Department of Civil Engineering, The University of Hong Kong, Hong Kong.

Williams C, Tsang WF.1988. Determination of structural parameters from full-scale vibration tests. In proceedings of Conference on Civil Engineering Dynamics, Society for Earthquake and Civil Engineering Dynamics, Bristol, UK, March 1988; 43-60. 
Table 1: Effect of infill walls on RC buildings/frames

\begin{tabular}{|c|c|c|c|c|c|c|}
\hline \multirow{2}{*}{$\begin{array}{l}\text { Literature } \\
\text { Reference }\end{array}$} & \multirow[t]{2}{*}{ Type of Investigation } & \multicolumn{3}{|c|}{ Building/Frame model } & \multirow{2}{*}{$\begin{array}{c}\text { Ratio of } \\
\text { stiffness } \\
\text { [infilled } \\
\text { frame/bare } \\
\text { frame] }\end{array}$} & \multirow{2}{*}{$\begin{array}{c}\begin{array}{c}\text { Ratio of } \\
\text { lateral } \\
\text { resistance } \\
\text { (strength) }\end{array} \\
\text { [infilled } \\
\text { frame/bare } \\
\text { frame] }\end{array}$} \\
\hline & & & $\begin{array}{l}\text { No. of } \\
\text { storeys }\end{array}$ & Scale & & \\
\hline $\begin{array}{l}\text { Bertero \& } \\
\text { Brokken } \\
\text { (1983) }\end{array}$ & $\begin{array}{l}\text { Analytical \& } \\
\text { Experimental (quasi- } \\
\text { static cyclic and } \\
\text { monotonic load test) }\end{array}$ & $\begin{array}{l}\text { Lower } 3-1 / 2 \text { stories } \\
\text { of } 3 \text {-bay RC frame } \\
\text { (infilled in the outer } \\
\text { two bays) }\end{array}$ & 11 & 0.33 & $3.5 \sim 11.7$ & $4.8 \sim 5.8$ \\
\hline $\begin{array}{l}\text { Shing et al. } \\
(1994) \\
\text { and } \\
\text { Mehrabi et } \\
\text { al. (1996) }\end{array}$ & $\begin{array}{l}\text { Analytical (simple } \\
\text { analytical and } \\
\text { inelastic FE analysis) } \\
\text { and Experimental } \\
\text { (cyclic and } \\
\text { monotonic load test) }\end{array}$ & $\begin{array}{l}\text { Single bay frame } \\
\text { (infilled with hollow } \\
\text { and solid masonry } \\
\text { panels) }\end{array}$ & 1 & 0.5 & $\begin{array}{l}\text { 15 (weak } \\
\text { frame- } \\
\text { weak } \\
\text { panel) } \\
\sim 50 \text { (weak } \\
\text { frame- } \\
\text { strong } \\
\text { panel) }\end{array}$ & $\begin{array}{l}\sim 1.5 \text { (weak } \\
\text { frame- } \\
\text { weak } \\
\text { panel) } \\
\sim 2.3 \text { (weak } \\
\text { frame- } \\
\text { strong } \\
\text { panel) }\end{array}$ \\
\hline $\begin{array}{l}\text { Negro and } \\
\text { Verzeletti } \\
\text { (1996) }\end{array}$ & $\begin{array}{l}\text { Experimental (pseudo } \\
\text { dynamic tests) }\end{array}$ & $\begin{array}{l}\text { RC building (only } \\
\text { two external frames } \\
\text { are infilled with } \\
\text { hollow brick masonry } \\
\text { panels) }\end{array}$ & 4 & 1 (full) & $\sim 2.6$ & $\sim 1.6$ \\
\hline $\begin{array}{l}\text { Chaker and } \\
\text { Cherifati } \\
\text { (1999) }\end{array}$ & $\begin{array}{l}\text { Analytical \& } \\
\text { Experimental } \\
\text { (vibration } \\
\text { measurement) }\end{array}$ & $\begin{array}{l}\text { Two adjacent RC } \\
\text { buildings (infilled } \\
\text { with hollow clay } \\
\text { brick panels) }\end{array}$ & 3 & 1 (full) & $\sim 7$ & $\begin{array}{l}\text { Not } \\
\text { evaluated }\end{array}$ \\
\hline $\begin{array}{l}\text { Yong Lu } \\
\text { (2002) }\end{array}$ & $\begin{array}{l}\text { Analytical } \\
\text { (Numerical analysis) } \\
\text { \& Experimental } \\
\text { (earthquake } \\
\text { simulation tests) } \\
\end{array}$ & $\begin{array}{l}\text { Four three bay } \\
\text { framed structures } \\
\text { (partially infilled with } \\
\text { masonry panels) }\end{array}$ & 6 & 0.18 & $>1.2$ & $>1.2$ \\
\hline $\begin{array}{l}\text { Lee and } \\
\text { Woo } \\
(2002)\end{array}$ & $\begin{array}{l}\text { Experimental } \\
\text { (earthquake } \\
\text { simulation test and } \\
\text { pushover test) }\end{array}$ & $\begin{array}{l}\text { 2-bay RC frame } \\
\text { (infilled with } \\
\text { masonry panels) }\end{array}$ & 3 & 0.2 & 5.6 & 4.0 \\
\hline
\end{tabular}


Table 2: Results of ambient vibration tests

\begin{tabular}{|l|l|l|l|}
\hline Building & Mode Number & Period (sec) & Vibration Direction \\
\hline \multirow{3}{*}{ Swire Building (SB) } & 1 & 0.60 & X-Translation \\
\cline { 2 - 5 } & 2 & 0.57 & Y-Translation \\
\cline { 2 - 4 } & 3 & 0.42 & Torsion \\
\hline \multirow{3}{*}{ T. T. Tsui Building (TTT) } & 1 & 0.58 & Y-Translation \\
\cline { 2 - 5 } & 2 & 0.56 & X-translation \\
\cline { 2 - 4 } & 3 & 0.38 & Torsion \\
\hline \multirow{3}{*}{$\begin{array}{l}\text { Typical Harmonly Block } \\
\text { Building (THB) }\end{array}$} & 1 & 1.54 & Y-Translation \\
\cline { 2 - 5 } & 2 & 1.39 & X-Translation \\
\cline { 2 - 4 } & 3 & 1.28 & \\
\hline
\end{tabular}

Table 3: Comparison of fundamental lateral period (sec) with the code-based formulations

\begin{tabular}{|l|l|l|l|l|}
\hline Building & Height $(\mathrm{m})$ & Experimental Result & $\begin{array}{c}\text { IBC-2000 } \\
\left(\mathrm{T}=0.073 \mathrm{H}^{3 / 4}\right)\end{array}$ & $\begin{array}{c}\text { Australian Standard } \\
{[\mathrm{AS} 1170.4(1993)]} \\
(\mathrm{T}=0.0217 \mathrm{H})\end{array}$ \\
\hline SB & 51.25 & 0.60 (Y-Translation) & 1.40 & 1.11 \\
\hline TTT & 52.84 & 0.58 (Y-Translation) & 1.43 & 1.15 \\
\hline THB & 112.7 & 1.39 (X-Translation) & 2.53 & 2.45 \\
\hline
\end{tabular}


Table 4: Results of numerical FE modelling

a) Swire Building (SB)

\begin{tabular}{|l|l|c|c|c|c|l|l|}
\hline \multirow{2}{*}{$\begin{array}{l}\text { Vibration } \\
\text { Direction }\end{array}$} & \multicolumn{7}{|c|}{ Vibration period (sec) } \\
\cline { 2 - 8 } & $\begin{array}{l}\text { (a) Bare } \\
\text { Frame }\end{array}$ & (b) & (c) & (d) & (e) & $\begin{array}{l}\text { (f) Full } \\
\text { frame }\end{array}$ & Result \\
\hline X-Translation & 1.22 & 1.06 & 0.61 & 1.04 & 0.94 & $\begin{array}{l}0.58 \\
(4 \%)\end{array}$ & 0.60 \\
\hline Y-Translation & 1.59 & 1.37 & 0.57 & 1.37 & 1.23 & $\begin{array}{l}0.56 \\
(3 \%)\end{array}$ & 0.57 \\
\hline Torsion & 0.97 & 0.84 & 0.47 & 0.84 & 0.75 & $\begin{array}{l}0.45 \\
(6 \%)\end{array}$ & $\begin{array}{l}0.42 \\
(6 \%)\end{array}$ \\
\hline
\end{tabular}

b) T. T. Tsui Building (TTT)

\begin{tabular}{|c|c|c|c|c|c|c|c|}
\hline \multirow{3}{*}{$\begin{array}{l}\text { Vibration } \\
\text { Direction }\end{array}$} & \multicolumn{7}{|c|}{ Vibration period (sec) } \\
\hline & \multicolumn{6}{|c|}{ Building Models } & \multirow{2}{*}{$\begin{array}{l}\text { Test } \\
\text { Result }\end{array}$} \\
\hline & $\begin{array}{l}\text { (a) Bare } \\
\text { Frame }\end{array}$ & (b) & (c) & (d) & (e) & $\begin{array}{l}\text { (f) Full } \\
\text { frame }\end{array}$ & \\
\hline X-Translation & 1.88 & 1.63 & 0.57 & 1.62 & 1.57 & $\begin{array}{l}0.55 \\
(2 \%)\end{array}$ & 0.56 \\
\hline Y-Translation & 1.51 & 1.32 & 0.59 & 1.30 & 1.25 & $\begin{array}{l}0.59 \\
(1 \%)\end{array}$ & 0.58 \\
\hline Torsion & 1.61 & 1.40 & 0.37 & 1.40 & 1.33 & $\begin{array}{l}0.36 \\
(5 \%)\end{array}$ & 0.38 \\
\hline
\end{tabular}

c) Typical Harmony Block Building (THB)

\begin{tabular}{|c|c|c|c|c|c|c|c|}
\hline \multirow{3}{*}{$\begin{array}{l}\text { Vibration } \\
\text { Direction }\end{array}$} & \multicolumn{7}{|c|}{ Vibration period (sec) } \\
\hline & \multicolumn{6}{|c|}{ Building Models } & \multirow{2}{*}{$\begin{array}{l}\text { Test } \\
\text { Result }\end{array}$} \\
\hline & $\begin{array}{l}\text { (a) Bare } \\
\text { Frame }\end{array}$ & (b) & (c) & (d) & (e) & $\begin{array}{l}\text { (f) Full } \\
\text { frame }\end{array}$ & \\
\hline X-Translation & 2.61 & 2.33 & 1.57 & 2.01 & 1.52 & $\begin{array}{l}1.25 \\
(-2 \%)\end{array}$ & 1.28 \\
\hline Y-Translation & 2.77 & 2.47 & 1.67 & 2.31 & 1.62 & $\begin{array}{l}1.38 \\
(-1 \%)\end{array}$ & 1.39 \\
\hline Torsion & 2.62 & 2.34 & 1.92 & 2.23 & 1.97 & $\begin{array}{l}1.55 \\
(0 \%)\end{array}$ & 1.54 \\
\hline
\end{tabular}

* Values in () represent the percentage difference between the full frame model and the test result. 
Table 5: Contributions to lateral stiffness arising from different sources

a) Swire Building (SB)

\begin{tabular}{|c|l|l|l|l|}
\hline Building Model & Vibration Direction & $\begin{array}{l}\text { Period } \\
(\mathrm{sec})\end{array}$ & $\begin{array}{l}\text { Modal } \\
\text { Participation Mass } \\
\text { ratio (\%) }\end{array}$ & $\begin{array}{l}\text { Stiffness } \\
\text { Contributed (\% } \\
\text { of total stiffness) }\end{array}$ \\
\hline \multirow{2}{*}{$\begin{array}{c}\text { Bare Frame } \\
\text { (Model a) }\end{array}$} & X-Translation & 1.22 & 51.2 & 21.6 \\
\cline { 2 - 4 } & Y-Translation & 1.59 & 53.0 & 10.5 \\
\hline \multirow{2}{*}{$\begin{array}{c}\text { Modified E-value } \\
\text { (Model b-Model a) }\end{array}$} & X-Translation & 1.06 & 51.0 & 6.9 \\
\cline { 2 - 5 } & Y-Translation & 1.37 & 53.0 & 3.6 \\
\hline \multirow{2}{*}{$\begin{array}{c}\text { NSC } \\
\text { (Model c-Model b) }\end{array}$} & X-Translation & 0.61 & 52.0 & 61.1 \\
\cline { 2 - 5 } & Y-Translation & 0.57 & 62.9 & 81.9 \\
\hline $\begin{array}{c}\text { Secondary Beam } \\
\text { (Model d- Model b) }\end{array}$ & X-Translation & 1.04 & 51.2 & 1.6 \\
\cline { 2 - 5 } $\begin{array}{c}\text { Flexible floor slabs } \\
\text { (Model e- Model b) }\end{array}$ & Y-Translation & 1.37 & 53.1 & 0.2 \\
\cline { 2 - 5 } & X-Translation & 0.94 & 51.7 & 8.8 \\
\hline \multirow{2}{*}{$\begin{array}{c}\text { Full Frame } \\
\text { (Model f) }\end{array}$} & X-Translation & 1.23 & 54.3 & 3.8 \\
\cline { 2 - 5 } & Y-Translation & 0.58 & 52.0 & 100.0 \\
\hline
\end{tabular}

b) T.T. Tsui Building (TTT)

\begin{tabular}{|c|l|l|l|l|}
\hline Building Model & Vibration Direction & $\begin{array}{l}\text { Period } \\
(\mathrm{sec})\end{array}$ & $\begin{array}{l}\text { Modal } \\
\text { Participation Mass } \\
\text { ratio (\%) }\end{array}$ & $\begin{array}{l}\text { Stiffness } \\
\text { Contributed } \\
\text { of total stiffness) }\end{array}$ \\
\hline \multirow{2}{*}{$\begin{array}{c}\text { Bare Frame } \\
\text { (Model a) }\end{array}$} & X-Translation & 1.88 & 68.5 & 9.0 \\
\cline { 2 - 5 } & Y-Translation & 1.51 & 53.1 & 11.1 \\
\hline $\begin{array}{c}\text { Modified E-value } \\
\text { (Model b-Model a) }\end{array}$ & X-Translation & 1.63 & 67.8 & 2.8 \\
\cline { 2 - 5 } & Y-Translation & 1.32 & 49.2 & 2.4 \\
\hline \multirow{2}{*}{$\begin{array}{c}\text { NSC } \\
\text { Model c-Model b) }\end{array}$} & X-Translation & 0.57 & 69.4 & 86.8 \\
\cline { 2 - 5 } $\begin{array}{c}\text { Secondary Beam } \\
\text { (Model d- Model b) }\end{array}$ & Y-Translation & 0.59 & 70.8 & 82.8 \\
\hline \multirow{2}{*}{$\begin{array}{c}\text { Flexible floor slabs } \\
(\text { Model e- Model b) }\end{array}$} & Y-Translation & 1.49 & 67.8 & 0.1 \\
\hline \multirow{2}{*}{$\begin{array}{c}\text { Full Frame } \\
\text { (Model f) }\end{array}$} & X-Translation & 1.24 & 48.5 & 0.2 \\
\cline { 2 - 5 } & Y-Translation & 1.57 & 70.2 & 1.3 \\
\cline { 2 - 5 } & Y-Translation & 1.25 & 55.6 & 3.5 \\
\hline
\end{tabular}


Table 5 (cont'd)

c) Typical Harmony Block Building (THB)

\begin{tabular}{|c|l|l|l|l|}
\hline Building & Vibration Direction & $\begin{array}{l}\text { Period } \\
(\mathrm{sec})\end{array}$ & $\begin{array}{l}\text { Modal } \\
\text { Participation Mass } \\
\text { ratio (\%) }\end{array}$ & $\begin{array}{l}\text { Stiffness } \\
\text { Contributed (\% } \\
\text { of total stiffness) }\end{array}$ \\
\hline \multirow{2}{*}{$\begin{array}{c}\text { Bare Frame } \\
\text { (Model a) }\end{array}$} & X-Translation & 2.61 & 67.7 & 24.0 \\
\cline { 2 - 5 } & Y-Translation & 2.77 & 66.7 & 25.0 \\
\hline \multirow{2}{*}{$\begin{array}{c}\text { Modified E-value } \\
\text { (Model b-Model a) }\end{array}$} & X-Translation & 2.33 & 67.8 & 6.2 \\
\cline { 2 - 5 } & Y-Translation & 2.47 & 66.8 & 6.5 \\
\hline \multirow{2}{*}{$\begin{array}{c}\text { NSC } \\
\text { Model c-Model b) }\end{array}$} & X-Translation & 1.57 & 53.7 & 22.4 \\
\cline { 2 - 5 } $\begin{array}{c}\text { Secondary Beam } \\
\text { (Model d- Model b) }\end{array}$ & Y-Translation & 1.67 & 52.1 & 22.5 \\
\hline \multirow{2}{*}{$\begin{array}{c}\text { Flexible floor slabs } \\
\text { (Model e- Model b) }\end{array}$} & Y-Translation & 2.01 & 63.3 & 7.7 \\
\hline \multirow{2}{*}{$\begin{array}{c}\text { Full Frame } \\
\text { (Model f) }\end{array}$} & X-Translation & 2.31 & 62.3 & 6.4 \\
\cline { 2 - 5 } & X-Translation & 1.52 & 66.6 & 39.6 \\
\cline { 2 - 5 } & Y-Translation & 1.62 & 64.9 & 39.7 \\
\hline
\end{tabular}

Table 6: Comparison of stiffness between bare-frame and full-frame models

\begin{tabular}{|l|l|c|}
\hline Building Model & $\begin{array}{l}\text { Vibration } \\
\text { Direction }\end{array}$ & $\begin{array}{c}\text { Ratio of stiffness } \\
\text { (full-frame/bare-frame) }\end{array}$ \\
\hline \multirow{2}{*}{ Swire Building (SB) } & X-Translation & 4.6 \\
\cline { 2 - 3 } & Y-Translation & 9.5 \\
\hline \multirow{2}{*}{ T. T. Tsui Building (TTT) } & X-Translation & 11.1 \\
\cline { 2 - 3 } & Y-Translation & 9.0 \\
\hline \multirow{2}{*}{$\begin{array}{l}\text { Typical Harmonly Block } \\
\text { Building (THB) }\end{array}$} & X-Translation & 4.2 \\
\cline { 2 - 3 } & Y-Translation & 4.0 \\
\hline
\end{tabular}


Figure1: Typical Floor Plans and Elevations of Buildings: (a) Swire Building (SB), (b) TT Tsui Building (TTT), and (c) Typical Harmony Block Building (THB)

Plan

(a)

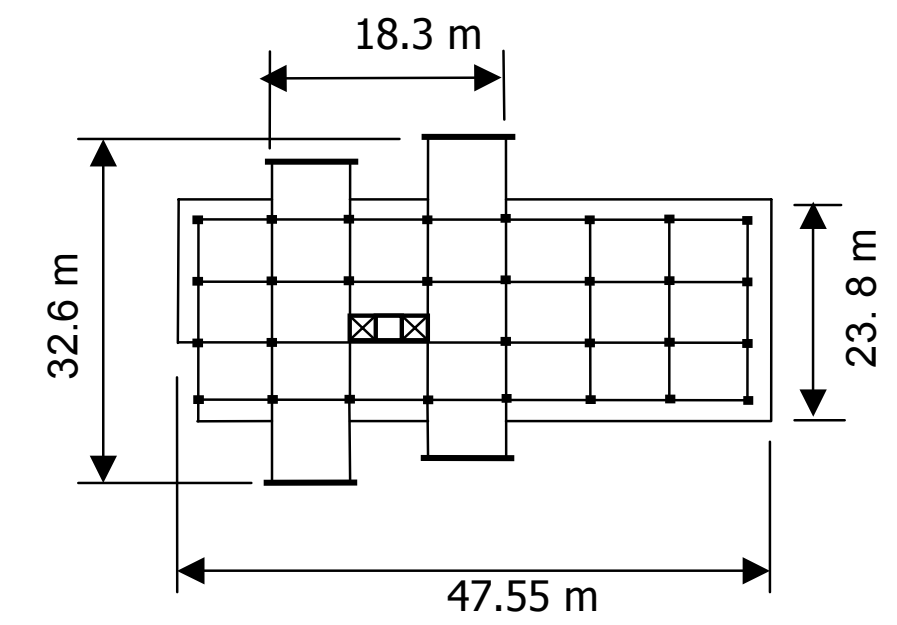

(b)

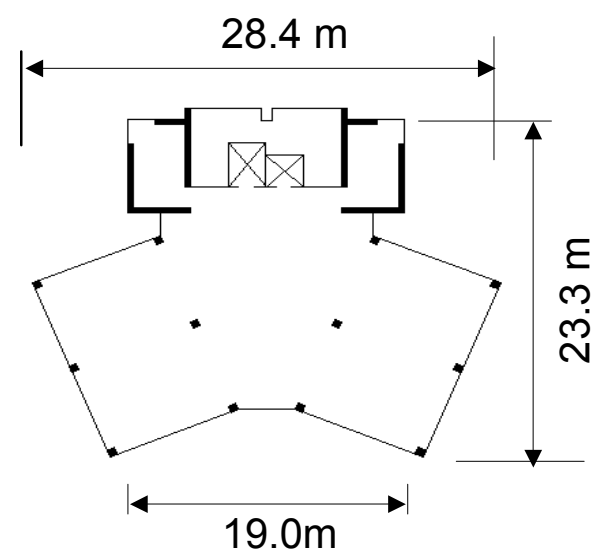

(c)

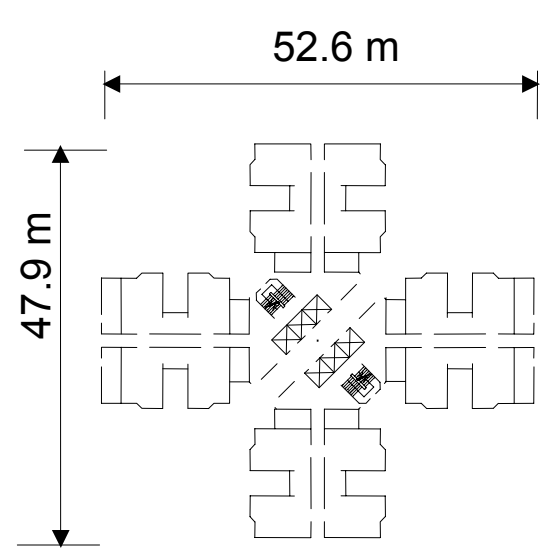

Elevation
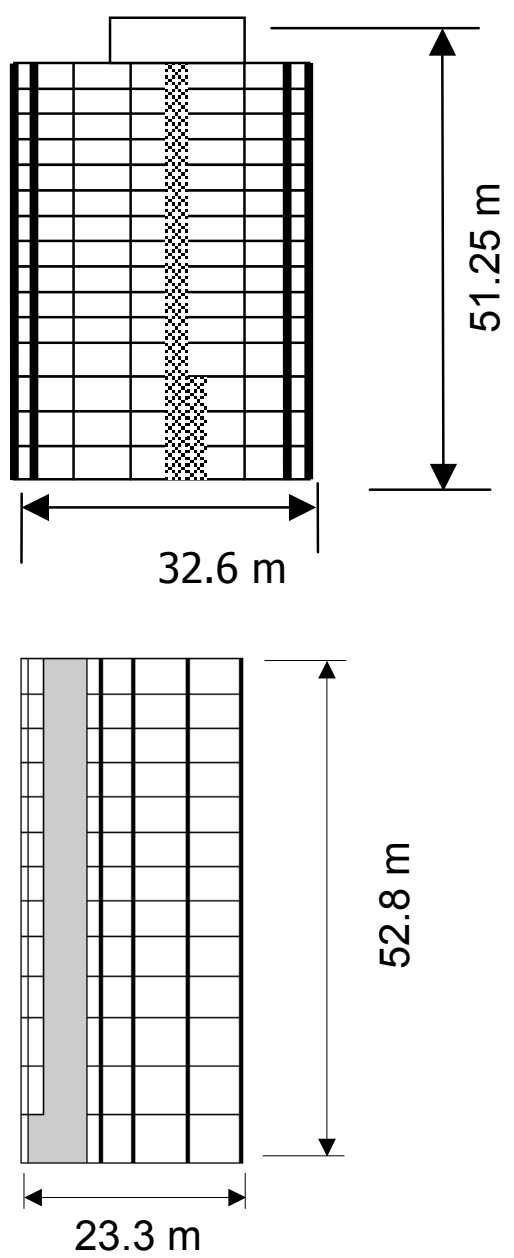

$\varepsilon$
$\infty$
Nิ

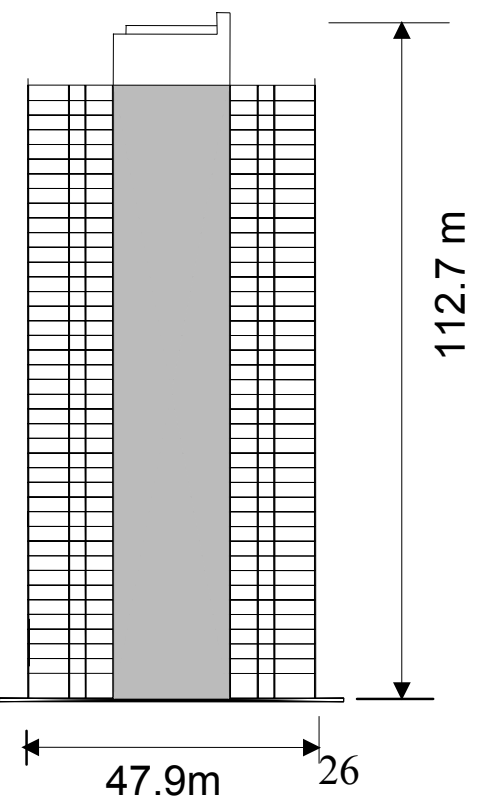


Figure 2: Schematic diagram of data acquisition system for ambient vibration testing

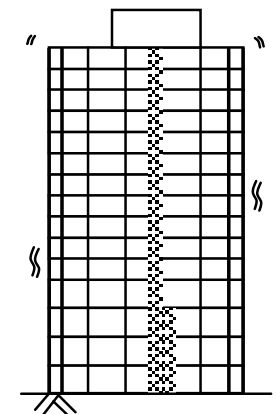

Vibration of building

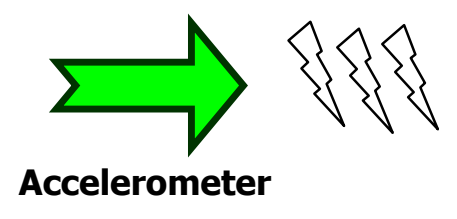

Electric current
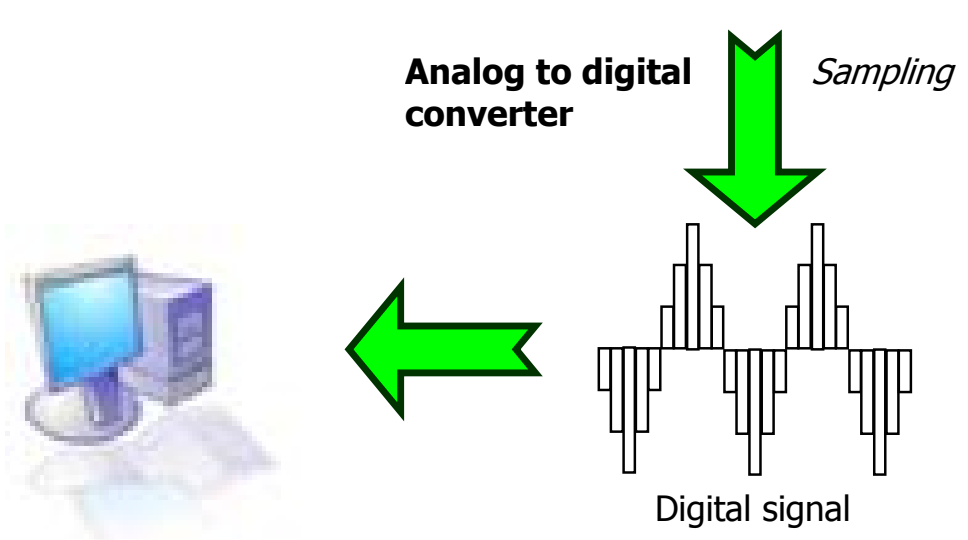

Data analysis by computer using GLOBAL LAB 
Figure 3: Arrangement of accelerometers in the buildings (a) Swire Building, (SB) (b) TTTsui Building (TTT), (c) Typical Harmony block building (THB)

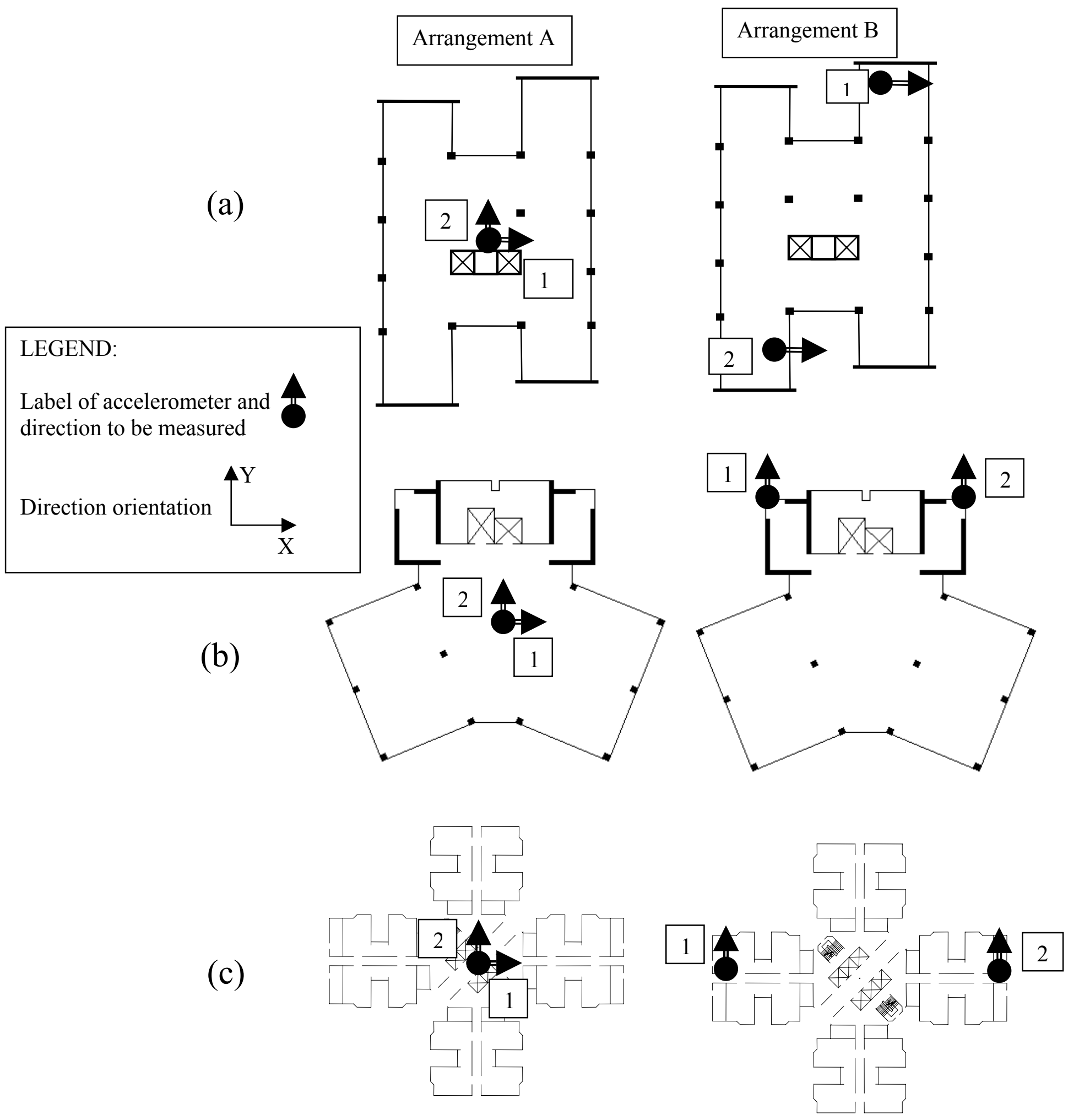


Figure 4a: Typical accelerometer time history for Swire Building SB (4 minutes duration)

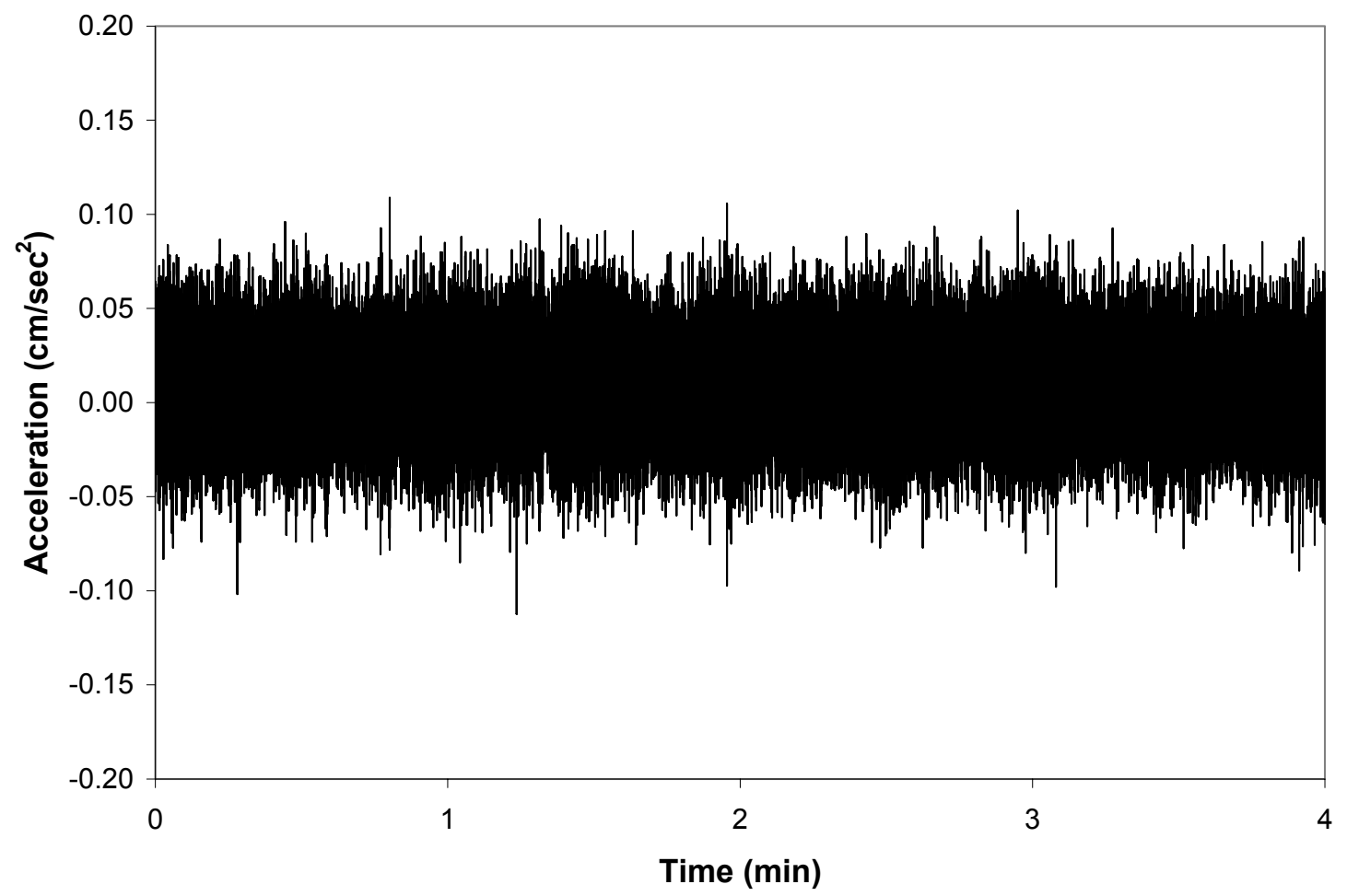


Figure 4b: Power spectrum of the time history without low pass filter

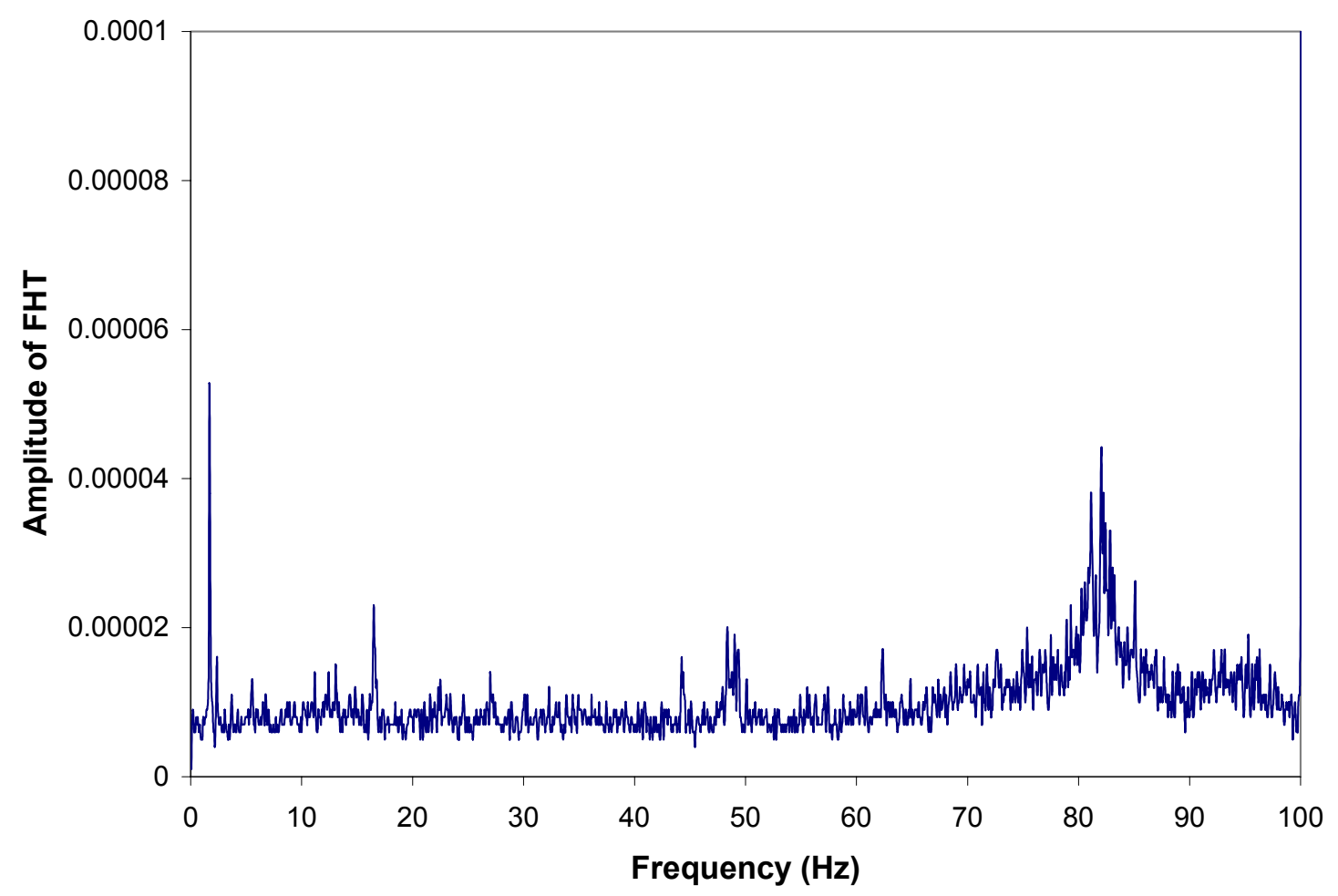

Figure 4c: Power spectrum of the time history after applying low pass filter of $10 \mathrm{~Hz}$.

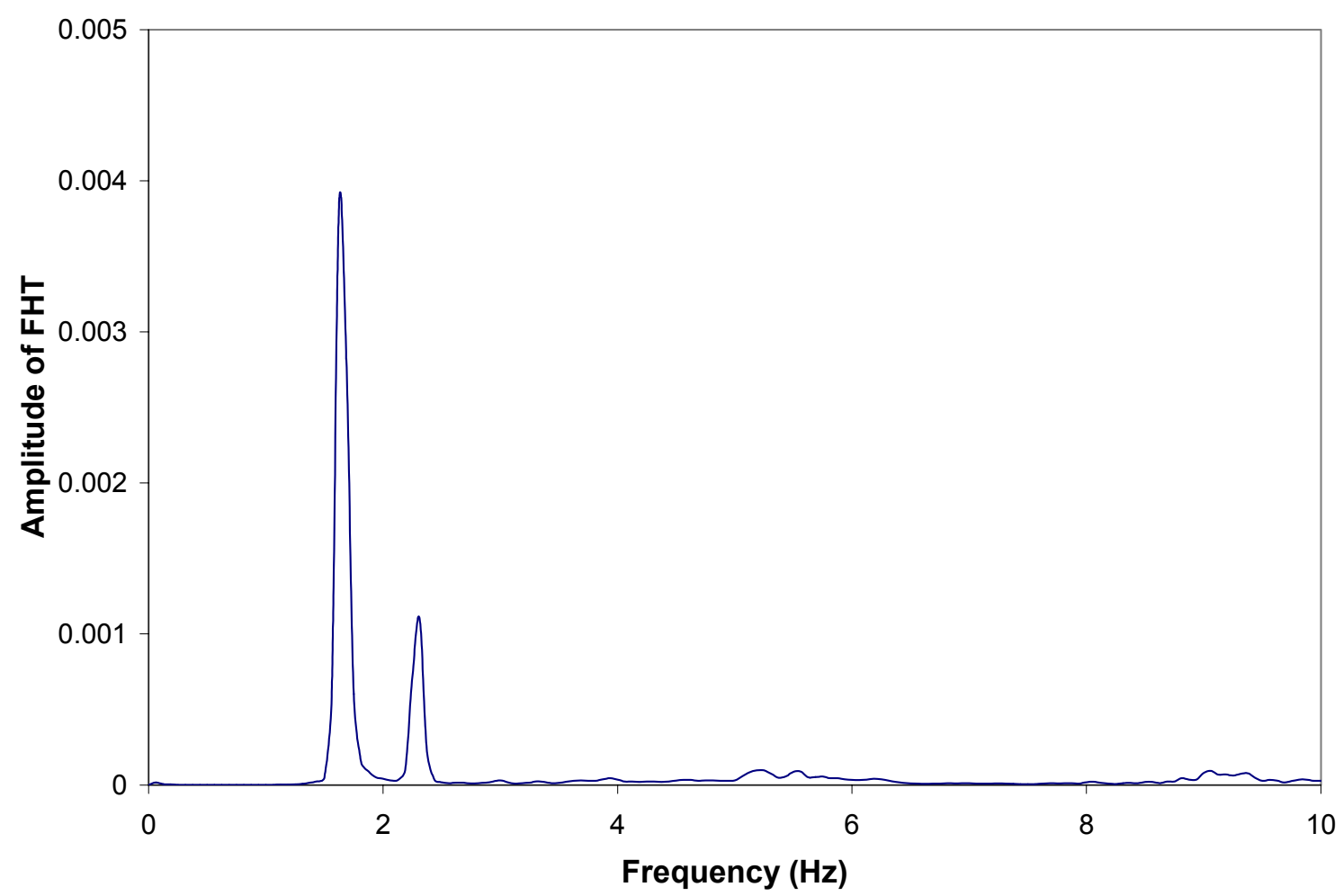


Figure 5: Numerical models (bare-frame and full-frame) of the buildings
a) Swire Building
(SB)

\section{b) TTTsui Building (TTT)}

\section{c) THB Building}

Bare-frame models
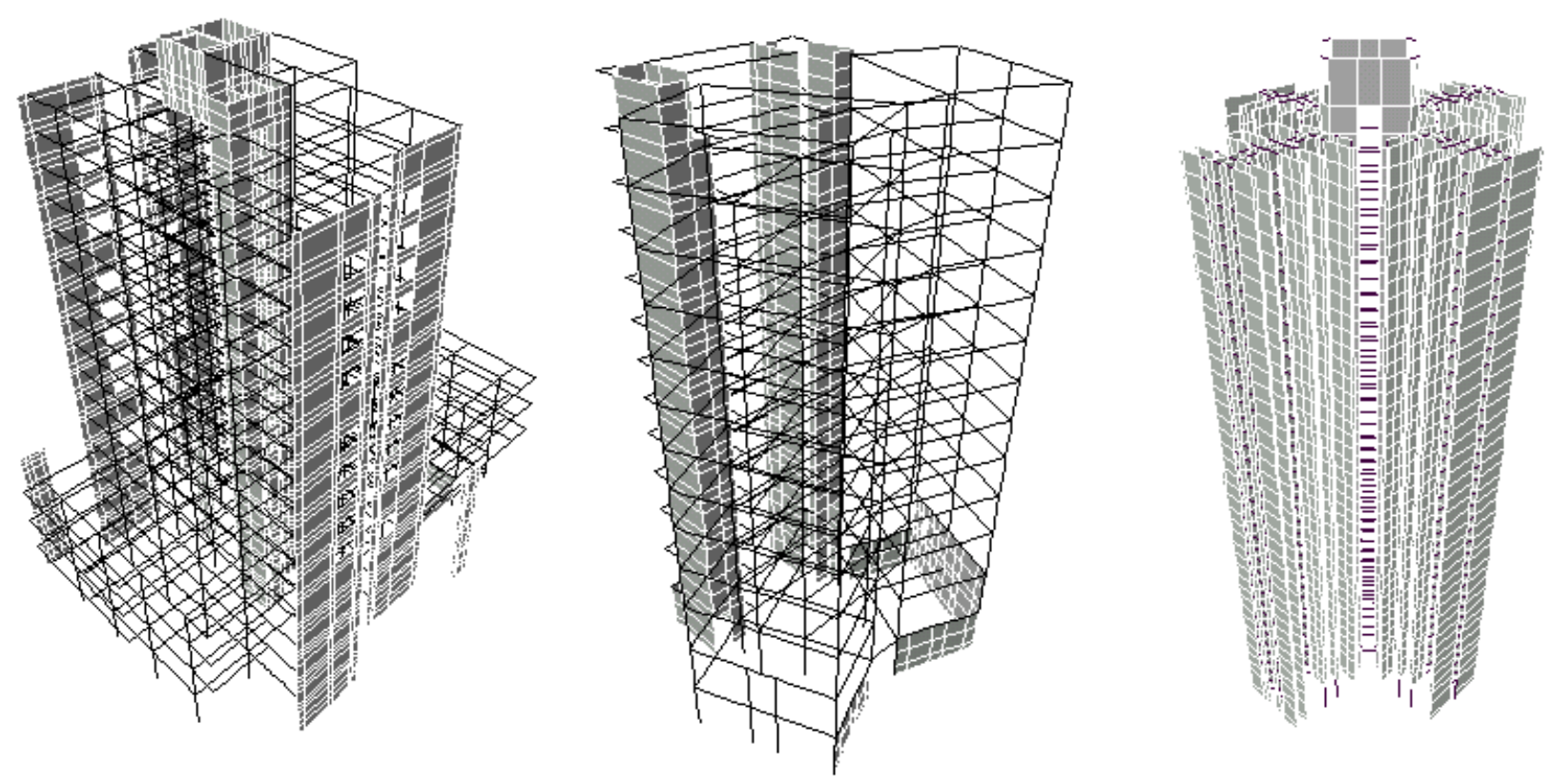

Full-frame models
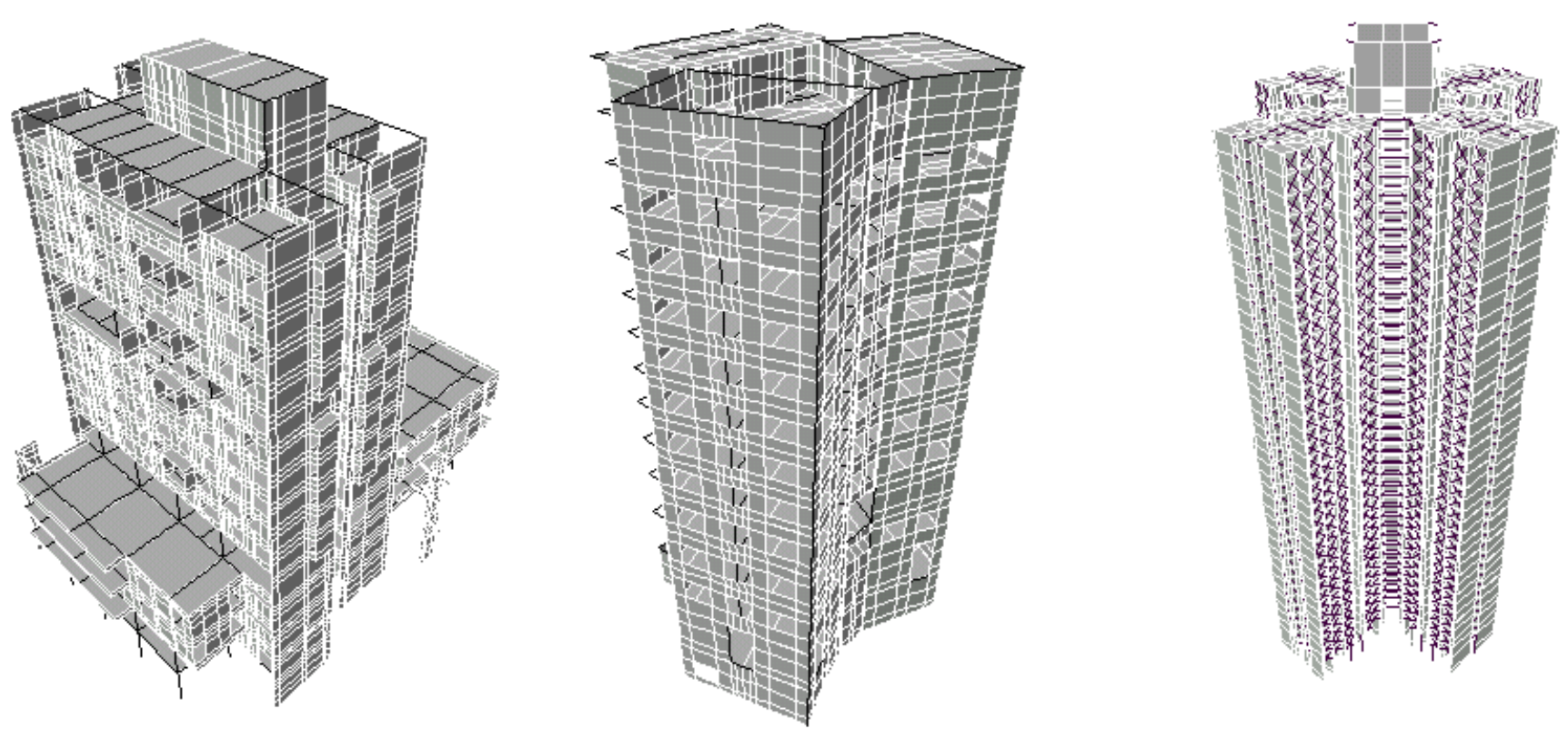

Figure 6: Stiffness contributions arising from different sources 


\section{X-direction}

(a) Swire Building (SB)

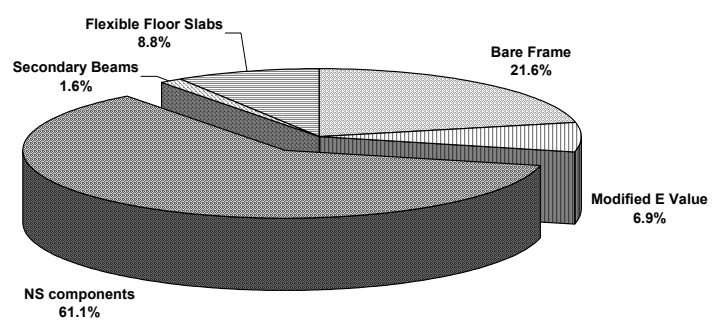

(b) TTTsui Building (TTT)

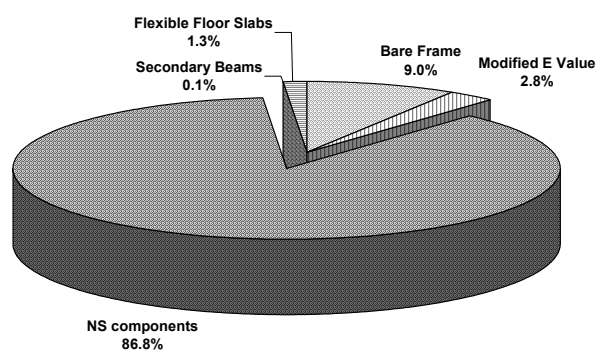

(c) Typical Harmony Block Building (THB)

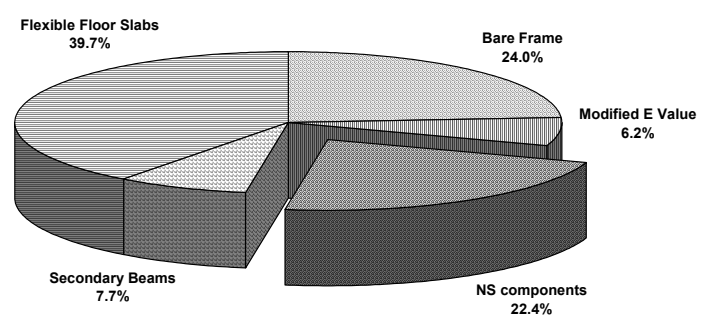

\section{Y-direction}
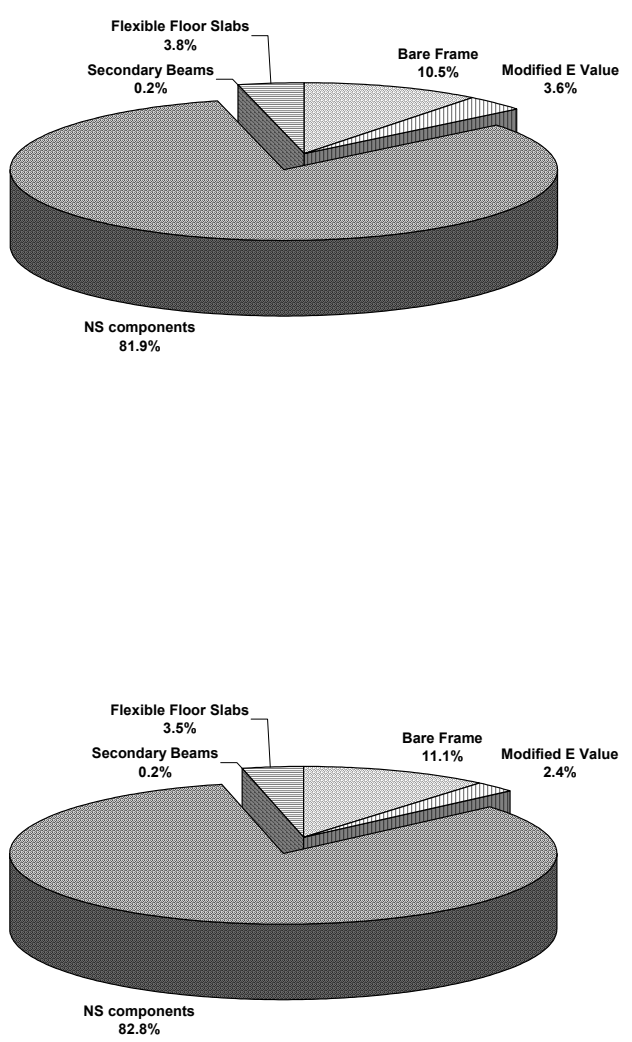